\title{
Some metabolic consequences of adaptation to muscular work
}

\author{
BY JANA PAŘfZKOVÁ aNd O. POUPA \\ Physical Culture Research Institute and Institute of Physiology, Czechoslovak \\ Academy of Sciences, Prague
}

(Received 26 November 1962-Revised 17 April 1963)

In individuals adapted to systematic and intense muscular exercise there is often a rapid increase in body-weight if output of energy is suddenly decreased by cessation of muscular work. This phenomenon is observed, for instance, in sportsmen who stop physical training. It may, however, also occur in the normal population when energy output is decreased for any reason, e.g. convalescence or change of employment, and sometimes this phenomenon may lead to obesity.

The mechanisms underlying this weight increase have not been described or analysed in any detail. In work now presented preliminary findings have been obtained to serve as the basis for further work.

\section{EXPERIMENTAL}

Subjects. A group of seven female gymnasts of the Czechoslovak National Team, who had trained for $7-8$ years on the average, was studied. Their mean age was 23 years. They were examined during routine training during the year, during preparation for the Olympic Games of 1960 and, after this preparation (I5 weeks), just before the Games and, finally, after $\mathrm{I} 6$ weeks of rest with relatively little training.

A further group of female gymnasts attending a sports school for 3-4 years (Pařizková, 1958) was also examined. Their mean age was 16 years. They were studied for 2 years during periods of training of varying intensity: before going to a summer training camp, i.e. after a period of training of average intensity; after the camp (3-4 weeks), i.e. after a period of more intense exercise; after a period of 6 weeks with relatively little physical activity. In the Ist year eleven and in the 2nd ten girls were examined; some of them were examined in both years.

Anthropometry. Body-weight, height and density together with skinfold thicknesses were measured. Skinfolds were measured by a caliper, constructed as described by Best (Best, 1954; Pařizková, 196r $b$ ), at ten selected sites (Allen, Peng, Chen, Huang, Chang \& Fang, I956; Pařizková, I 96 $b$ ): on the cheek, under the chin, on the chest in the anterior axillary fold, on the back of the arm, on the back underneath the angle of the scapula, on the chest in the anterior axillary line at the level of the tenth rib, on the abdomen, on the side above the iliac crest, on the thigh above the knee, on the calf below the popliteal fossa (Pařizková, 1959, 196ra). Body density was calculated from body-weight and body volume measured by means of hydrostatic weighing (Keys \& Brožek, 1953). The volume of the air in the lungs and respiratory passages was determined at the moment of weighing by the nitrogen-dilution method 
(Navrátil, Křeček \& Cvachová, 1958; Pařrzková, 1958, 1961 $b$ ) as modified by Cournand, Darling, Mansfield \& Richards (1940), the interferometer being used for analysis. Two successive determinations never differed by more than $0.5 \%$. Body composition was calculated from the formula of Keys \& Brožek (I953) and Brožek (1954):

$$
\text { Body density }=\frac{W_{a} \times D_{w}}{W_{a}-W_{w}^{\prime}-V \times D_{w}},
$$

where $W_{a}=$ body-weight $(\mathrm{kg})$ in air; $D_{w}=$ density of water at $35-36^{\circ}$, i.e. 0.995 ; $W_{w}^{\prime}=$ body-weight $(\mathrm{kg})$ in water; $V=$ volume (1.) of air in the lungs and respiratory passages at the time when $W_{w}^{\prime}$ was determined. Body composition of weight gain was calculated from the changes in body-weight and body volume by the method of Entenman, Goldwater, Ayres \& Behnke (1958).

Food consumption values. In the second group (sports school) intake of calories was estimated from nutritional diaries in which the amount and type of food consumed were entered. In the summer camp the reliability of this method was tested by measuring the amount of food distributed, and was found to be satisfactory. From these figures the intake of calories was evaluated quantitatively (total amount of calories consumed and the absolute and relative amounts of proteins, carbohydrates and fat).

\section{RESULTS}

Table 1 shows weights, skinfold thicknesses and body densities in gymnasts of the National Team after periods of different intensity of training. The mean body-weight during average and intensive training remained almost unchanged, but rose significantly in the period of relative rest. Body density, as an indicator of the ratio fat:lean body mass increased in the period of intense training, indicating a fall in fat content and a rise in lean body mass. In the period of relative rest, changes of an opposite nature occurred: density fell, fat content increased and lean body mass decreased. Similar changes were observed in skinfold thickness.

Table I. Mean values with their standard errors for body-weight, skinfold thickness and body density of seven female gymnasts of the Czechoslovak National Team after periods of average training, intensive training and relative rest

$\begin{array}{lccc} & \begin{array}{c}\text { After preparation for } \\ \text { After routine training } \\ \text { during the year }\end{array} & \begin{array}{c}\text { Olympic Games } \\ \text { (I5 weeks) }\end{array} & \begin{array}{c}\text { After I6 weeks } \\ \text { of rest }\end{array} \\ & \mathbf{r} \cdot 072 \pm 0.003 & 1 \cdot 077 \pm 0.004 & \mathbf{1} \cdot 069 \pm 0.004 \\ \text { Density } & 70 \pm 9 & 65 \pm 9 & 84 \pm 12 \\ \text { Total skinfold thickness }(\mathrm{mm}) & 55 \cdot 4 \pm \mathrm{r} \cdot 3 & 55 \cdot 2 \pm \mathrm{r} \cdot 5 & 57 \cdot 2 \pm \mathrm{I} \cdot 4\end{array}$

Similar changes were also found for younger gymnasts at the sports school, but during considerably shorter periods (Table 2). During summer camp in a period of most intensive training (Ist year, 4 weeks; 2nd year, 3 weeks), there was a slight rise in weight which was not significant. In periods of relatively little physical activity bodyweight increased significantly. Skinfold thickness fell in both years in periods of 
Table 2. Mean values with their standard errors for body-weight, skinfold thickness and body density of female gymnasts from a sports school after routine training during the year, after intensive training in a summer camp and after cessation of intensive training in 1959 and 1960

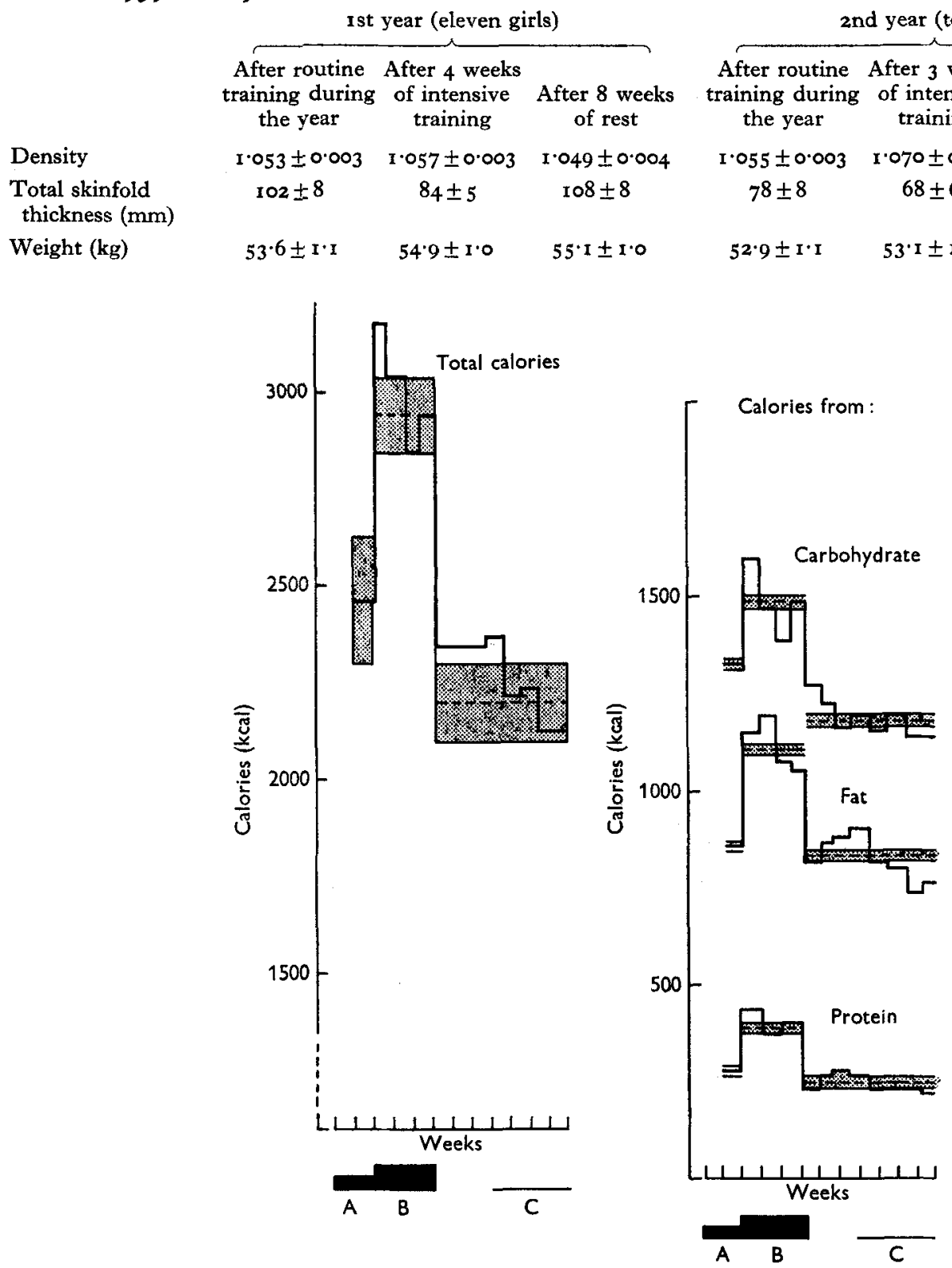

Fig. I. Changes in intake of total calories (left) and of calories derived from protein, fat and carbohydrate (right) by girls from the sports school in the periods of routine training (A), intensive training (B) and after cessation of intensive training (C). Shaded areas, standard errors of the mean. Relative intensity of training is shown below the abscissa; after $\mathrm{B}$, training was interrupted and then resumed at slight intensity at the beginning of the school year. 
intensive training and rose significantly after cessation of intensive training. Body density increased in periods of intensive training and fell in periods of relative rest, again indicating a fall in fat content and a rise in lean body mass during the former and the opposite tendencies during the latter periods.

An analysis of weight increases and their densities showed that body composition did not change solely by an increase in lean body mass during the period of intensive training or by an increase in fat during the period of relative rest; an increase in one was accompanied by a decrease in the other. Thus, the increase in lean body mass of some girls in the period of intensive training was greater than would correspond to the rise in body-weight, and similarly the fat content rose more after interruption of intensive training.

Fig. I shows that during average training (period A) intake of calories amounted to $2460 \mathrm{kcal} /$ day with the calories from protein, from carbohydrate and from fat in the ratio I : $: 54: 35$, as was measured in the 2nd year (1960). During intensive training (period B) intake of calories first increased to $3180 \mathrm{kcal} /$ day and then fell to $3027 \mathrm{kcal} /$ day and levelled off at about $2900 \mathrm{kcal} / \mathrm{day}$. The intake of calories from protein, from carbohydrate and from fat was in the ratio $13: 50: 37$. The increase in calorie intake was significant. During relative rest (period C) mean values for eight periods of 5-6 days fell to $2100-2300 \mathrm{kcal} /$ day, i.e. to values somewhat lower than those in period A. From period B to period C the value fell by $25 \%$. The total intake of protein in period C fell by $36 \%$, that of fat by $25 \%$ and that of carbohydrate by $20 \%$. The fall always was statistically significant. The ratio of calories from protein, from carbohydrate and from fat was almost the same in periods A and C, namely I : $54: 35$. It follows that during intensive training gymnasts consumed relatively more carbohydrate (significant rise by $2 \cdot 7 \%$ ) and less protein (significant fall by $2 \cdot 1 \%$ ) than in period $B$ and the relative fat intake remained unchanged.

\section{DISCUSSION}

Our findings show that interruption of intensive muscular work results in a rise in body-weight due to an increase in fat content of the body. In healthy normal individuals the cause of the weight increase is thought to be an imbalance between intake and output of calories. Such an imbalance might also explain the increased laying down of fat in individuals adapted to a high energy output, if during periods of decreased motor activity the high intake of calories is maintained. Our findings, however, show that during relative rest the intake of calories no longer persisted and fell to values found before intensive training began. Yet fat was laid down. The only difference observed was a relatively increased intake of carbohydrate and a fall in the relative amount of protein consumed. These changes, however, were so slight that they can hardly be considered as having caused the increased formation of fat.

It is probable that the increased laying down of fat during the period of relative rest that follows prolonged intensive physical exercise in man is not due to a disturbance of mechanisms regulating food intake but is caused by other mechanisms. Adaptation to intensive muscular work may result in systemic metabolic changes: it 
is known that during intensive muscular work fatty acid utilization in muscle is increased. This situation applies to man (Carlson \& Pernow, 1959, 196I), and some data from comparative physiology also support this concept (Odum \& Connell, 1956; George \& Naik, 1957). It is possible that there is adaptive transformation of metabolism caused by prolonged intensive muscular work which results in an increased deposition and slower release of fatty acids in fat depots during rest, when these acids are being utilized to a less extent by the muscle mass. This problem requires further study.

\section{SUMMARY}

I. Two groups of female gymnasts were studied (women of the Czechoslovak National Team and pupils of a sports school) during periods of average and intensive training and during relative rest. During rest body-weight increased owing to fat deposition, as shown by measurement of body density and of skin-fold thickness.

2. A record was kept of the food intake, which showed that during relative rest food consumption decreased by $25 \%$ compared to that in the period of intensive training.

3. During intensive training the ratio of the calorie intake from protein, from carbohydrate and from fat was $13: 50: 37$; during relative rest the calorie intake from protein fell by $2 \cdot 1 \%$ and that from carbohydrate rose by $2 \cdot 7 \%$.

4. It is considered that the increased accumulation of fat during rest after intensive training is not due to impairment of the regulation of food intake, but is the result of adaptive transformations of metabolic processes caused by previous muscular work. This hypothesis is discussed.

We are grateful to Ing. $Z$. Roth for his co-operation in statistical analysis of the results, to Miss V. Dobrovodská for co-operation in analysis of nutritional values and to Miss M. Svozilová for technical assistance.

\section{REFERENCES}

Allen, T. H., Peng, M. T., Chen, K. B., Huang, T. F., Chang, C. \& Fang, H. S. (1956). Metabolism, 3, 346.

Best, W. R. (1954). F. Lab. clin. Med. 43, 967.

Brožek, J. (1954). Methods for Evaluation of Nutritional Adequacy and Status, p. 265. A Symposium sponsored by the Quartermaster Food and Container Institute, University of Chicago, February I 954. Washington: National Academy of Sciences-National Research Council.

Carlson, L. A. \& Pernow, B. (1959). F. Lab. clin. Med. 53, 833 .

Carlson, L. A. \& Pernow, B. (196r). F. Lab. clin. Med. 58, 673.

Cournand, A. R., Darling, R. C., Mansfield, J. S. \& Richards, D. W. Jr. (1940). F. clin. Invest. Ig, 598.

Entenman, C., Goldwater, W. H., Ayres, N. S. \& Behnke, A. R. (1958). J. appl. Physiol. 13, 129.

George, J. C. \& Naik, R. M. (1957). F. Anim. Morphol. Physiol. 4, 23.

Keys, A. \& Brožek, J. (1953). Physiol. Rev. 33, 245.

Navrátil, M., Křeček, V. \& Cvachová, L. (1958). Čas. Lék. čes. 97, 782.

Odum, E. P. \& Connell, C. E. (1956). Science, 123, 892.

Pařízková, J. (1958). Čs. fysiol. 7, 234.

Pařízková, J. (1959). Physiol. bohemoslov. 8, 112.

Pařizková, J. (1961 a). Metabolism, 10, 794.

Pařizková, J. (196ı b). F. appl. Physiol. 16, 173. 